\title{
Investigation of the effects of antibacterial finishing on some mechanical properties of cotton sheet fabrics
}

DOI: $10.35530 / 1 T .072 .05 .1833$

CAN YAHYA

\begin{abstract}
REZUMAT
Investigation of the effects of antibacterial finishing on some mechanical properties of cotton sheet fabrics

In this article, it is aimed to determine the effect of the antibacterial finishing process applied to bed linen fabrics, which are widely used in the market, on some mechanical properties of the fabric. Antibacterial finishing process was applied to the fabric produced for this purpose under operating conditions and wrinkle strength, tear strength and abrasion resistance levels were made on these fabrics. Measurements were made before and after antibacterial finishing. The resulting results were evaluated among themselves and processed in SPSS (Statistical Package for Social Sciences) 21.0 program. Since the number of processed data is less than 50 according to greige fabric and antibacterial treated fabric measurements, it has been tested with Shapiro-Wilk analysis. The homogeneity of the test variances of the data was done with Levene homogeneity test. Tear strength, creasing angle and abrasion resistance test results are focused on how scientifically meaningful the effects of process parameters and interactions on fabric properties are in accordance with statistical analysis. As a result of the analysis, it was revealed that the results obtained from the tear strength, wrinkle angle and abrasion resistance tests were statistically significant and as a result, the antibacterial process parameters negatively affect the wrinkle strength, tear strength of the cotton fabric; it was found to affect the wear resistance positively.
\end{abstract}

Keywords: antibacterial textiles, medical textiles, greige fabric, wrinkle test, tear test, abrasion level

\section{Analiza influenței finisării antibacteriene asupra unor proprietăți mecanice ale țesăturilor din bumbac}

În acest articol, s-a urmărit determinarea influenței procesului de finisare antibacteriană aplicat țesăturilor pentru lenjeria de pat, care sunt utilizate pe scară largă pe piață, asupra unor proprietăți mecanice ale țesăturii. Procesul de finisare antibacteriană a fost aplicat țesăturiilor produse pentru acest domeniu de utilizare, iar rezistența la șifonare, rezistența la rupere și rezistența la abraziune au fost determinate pentru aceste țesături. Măsurătorile au fost efectuate înainte și după finisarea antibacteriană. Rezultatele au fost evaluate și prelucrate în programul SPSS 21.0 (Pachetul statistic pentru științe sociale). Deoarece numărul datelor prelucrate este mai mic de 50, în funcție de determinările efectuate pe țesătura crudă și pe țesăturile tratate antibacterian, acestea au fost testate cu analiza Shapiro-Wilk. Omogenitatea varianțelor de testare a datelor a fost realizată cu testul de omogenitate Levene. Rezistența la rupere, unghiul de șifonare și rezultatele testelor de rezistență la abraziune sunt axate pe cât de semnificativă din punct de vedere științific este influența parametrilor procesului și interacțiunile asupra proprietăților țesăturii, în conformitate cu analiza statistică. Ca rezultat al analizei, s-a demonstrat că datele obținute din testele de rezistență la rupere, unghiul de șifonare și rezistența la abraziune au fost semnificative din punct de vedere statistic și, prin urmare, parametrii procesului antibacterian influențează negativ rezistența la șifonare și rezistența la rupere a țesăturii de bumbac; s-a constatat că influențează pozitiv rezistența la abraziune.

Cuvinte-cheie: textile antibacteriene, textile medicale, țesătură crudă, test de rezistență la șifonare, test de rezistență la rupere, nivel de abraziune

\section{INTRODUCTION}

Hospital beds in the hospital environment used like bed sheets, bedspreads and pillows microorganisms placed between textile structures damage to the textile product itself and the user can give. In this study; After giving general information about woven fabric, factors affecting fabric characteristics hospital infections, after antibacterial finishing treatment applied to bed linen fabrics used in the hospital, it was investigated how the fabric affects the wrinkle strength, tear strength and abrasion resistance properties of cotton fabric. Odor and color change in textile products where bacteria reproduce and loss of quality and performance [1]. Many researchers have done studies for the effectiveness of bacteria in fabrics. Isys AG was used in antibacterial dispersion fabrics containing silver ions. Cotton/Polyester blends are used to combine the water absorbency and natural properties of cotton and the durability of polyester. In addition, with this mixture, along with the price advantage of polyester, a decrease in product price is observed. Such sheets can be used longer. They show similar properties with $100 \%$ cotton fabric antimicrobially [2]. It is the application of the finishing agent that will change the properties of use or appearance, dissolved/ homogeneously dispersed in a liquid to the 
fabric [3]. Perelshtein et al. [4] revealed excellent antibacterial activity against Ag-fabric Escherichia coli (gram-negative) and Staphylococcus aureus (grampositive) cultures. Balakumaran et al. [5] investigated AgNP-coated cotton fabrics exhibited broad-spectrum antibacterial activity against all tested pathogens. HR-SEM micrographs of cotton fabrics coated with AgNPs exhibited a rough surface, and the presence of nanoparticles on the cotton surface was also observed and demonstrated the importance of developing this method. The treated cotton fabric Escherichia coli and Staphylococcus aureus bacterial reduction efficiency resulted in good quantitative and qualitative antimicrobial activity. They showed excellent resistance to biodegradation caused by soil microflora. They also demonstrated the high durability of antimicrobial activities obtained even after 20 wash cycles; where $E$. coli and $S$. aureus achieved a $99.1 \%$ and $98.7 \%$ reduction in the number of bacteria, respectively [6]. The antibacterial fabric with $758 \mathrm{mg} / \mathrm{kg}$ silver nanoparticles on surface cotton was highly effective in killing test bacteria and had excellent water resistance [7]. It is a simple and inexpensive procedure to prepare antibacterial cotton fabric using silver nanoparticles (AgNPs) and biodegradable GT. To investigate the effectiveness of antibacterial power, different concentrations of GT (2, 4 and $6 \mathrm{~g} / \mathrm{l})$ were applied, together with a constant amount of $\mathrm{Ag}$ (5\%; based on the weight of dry GT used in solutions). The effects of E. coli and Staphylococcus aureus cotton fabric on their physical, mechanical and biological properties and the presence of a small amount of composite structure AgNP were sufficient to increase the antibacterial activity of fabrics compared to only GT treated fabric [8]. Kittinaovarat et al. made to use glycosal and chitosan in a single-stage finishing process in order to give antibacterial efficacy with durable press performance to cotton fabrics. The Glyoxal process provided good wrinkle-resistant properties and fair antibacterial activity on the finished fabrics, but there was a decrease in the tensile strength of the finished fabrics. Added to the combination of this system, chitosan gave similar results in wrinkle-resistant and antibacterial properties, as did glycosal on finished fabrics. The advantage of chitosan in the combination of glycosal and chitosan system was that it did not adversely affect the breaking strength [9]. The coating of Ag NPs on cotton fabric showed excellent antibacterial properties and washing resistance, after 50 consecutive wash cycles for $S$. aureus and $E$. coli. Bacterial reduction rates (BR) versus E. coli remained above 95\% [10]. QingBo Xu et al. investigated L-cysteine (Cys) and silver nanoparticles (Ag NPs) that were successfully bonded to cotton fabric surfaces. Bacterial reduction rates (BR) efficacy for scherichia $E$. coli and $S$. aureus reached $100 \%$. After 50 consecutive wash cycles, bacterial reduction rates $(\mathrm{BR})$ against $E$. coli and $S$. aureus were kept above 97\% [11].

\section{MATERIAL}

It is decided to use the most woven cotton cloth foot sheet which antibaterial \%100 cotton plan fabrics in the hospitals for use in the experiments. The fabric is woven in a Picanol air-jet weaving machine with a width of $240 \mathrm{~cm}$. Burning, desizing, bleaching, optical bleaching and calendering processes were carried out in the operating environment, respectively. The substance called Isys AG is a silver-containing dispersion, a textile finishing product with a bacteriostatic effect. K A good antibacterial activity was observed against the MRSA isolate in the fabric, and it was observed that the fabric showed a weak antibacterial activity against the E.coli isolate. No antibacterial activity of the fabric against other 4 bacteria was observed. The effectiveness of antibacterial activity will decrease depending on the type of chemical substance that has antibacterial effect, the duration of its activity on the fabric, and physical factors such as washing and wear. In general, antibacterial termination was found to be effective against MRSA and $E$. coli, which are common isolates of hospital infections.

\section{METHOD}

In the research, it was aimed to compare the greige fabric with the antibacterial fabric by making measurements in terms of wrinkle strength, tear strength and abrasion resistance. Within the scope of the research, data collected as warp and weft in terms of wrinkle and tear strength of greige fabric and antibacterial treated fabric and data collected in terms of abrasion resistance were processed into SPSS (Statistical Package for Social Sciences) 21.0 program. Since the number of processed data is less than 50 according to greige fabric and antibacterial treated fabric measurements, it has been tested with Shapiro-Wilk analysis. The homogeneity of the test variances of the data was done by Levene homogeneity test. $111 \mathrm{~g} / \mathrm{m}^{2}$ of greige plain woven fabric 30 warp per $\mathrm{cm}$ every warp 740 tour per m, 26 weft per $\mathrm{cm}$ and weft yarn 600 tour/m. The pre-finishing of our woven cotton fabric was carried out in the dyehouse environment. In the laboratory, the physical properties of the fabric before and after processing were measured and compared.

Test results were recorded in SPSS (Statistical Package for Social Sciences) 21.0 program. Since the number of processed data is less than 50 according to greige fabric and antibacterial treated fabric measurements, it has been tested with Shapiro-Wilk analysis. The homogeneity of the test variances of the data was done by Levene homogeneity test. iSys AG is sensitive to over $40^{\circ} \mathrm{C}$ and cold; Permanent changes occur at temperatures close to the freezing point. Thanks to its nano-sized silver content, the antimicrobial property, which is very well achieved with iSys $A G$, is obtained and this process is done in scarfs. Prepare $10.0 \mathrm{~g} / \mathrm{l}$ iSys MTX, $0.5 \mathrm{~g} / \mathrm{l}$ iSys AG, $20.0 \mathrm{~g} / \mathrm{I}$ TUBINGAL HWS, $0.5 \mathrm{~g} / \mathrm{K} \mathrm{KOLLASOL}$ CDO at $\mathrm{pH}$ 5.5. Pick-up $100 \%$ Drying is fixed at $120^{\circ} \mathrm{C}$ veC 
and $170^{\circ} \mathrm{C}$, fix for 30 seconds Tests on the fabric were checked by processing and processed fabric samples. 6 different bacterial isolates (MRSA) ATCC 43300, Enterococcus faecalis ATCC 29212, Streptococcus pneumoniae ATCC 49619, Escherichia coli ATCC 25922, Klebsiella pneumoniae ATCC 700603 ve Pseudomonas aeruginosa ATCC 27853) in the microbiology laboratory were apliciated. AATCC 147 diffusion method and AATCC 100 are quantitative analysis methods [12]. In AATCC 147, diffusion test method, pre-prepared bacterial concentrations are poured into the medium and then $25 \mathrm{~mm}$ diameter sample fabrics are placed. After the sample fabrics are kept at $37^{\circ} \mathrm{C}$ for 24 hours, the effectiveness of the sample fabric is determined by measuring the diameter formed around the fabric (inhibition zone diameter).

In the Agar Diffusion Method, which is a quantity method, the antibacterial activity of antimicrobial treated fabrics can be observed and comments can be made about the effectiveness (Palamut et al.). Tear strength tests of sample fabrics were carried out in the ElmaTear Digital Tear Strength Meter in accordance with the TS EN ISO 13937-1 standard. Test samples are $100+/-2 \mathrm{~mm}$ long and $75+/-2 \mathrm{~mm}$ wide. $20+/-0.5 \mathrm{~mm}$ notch is opened from the lower middle part of the sample. 5 different experiments are carried out in the direction of weft and warp and the average of these values is given as the average tear strength [13]. Determination of the abrasion resistance of the sample fabrics was made 15 times from two different fabrics that had undergone antibacterial treatment for Martindale crease angle test based on TS EN ISO 12945-1 standard. The numbers in table 1 are the arithmetic mean of the different number of measurements as per the standard. Fabric creasing angle was measured separately for weft and warp direction. In samples measured for both weft and warp direction; half of the sample was measured with the fabric side facing the fabric and the other half with the fabric opposite.

\begin{tabular}{|c|c|c|c|c|}
\hline \multicolumn{5}{|c|}{$\begin{array}{r}\text { WRINKLE ANGLE TESTS FOR GREIGE FABRIC } \\
\text { AND ANTIBACTERIAL FABRIC (ISO 2313) }\end{array}$} \\
\hline \multirow{3}{*}{ Samples } & \multicolumn{2}{|c|}{$\begin{array}{c}\text { Greige fabric } \\
\text { (degree) }\end{array}$} & \multicolumn{2}{c|}{$\begin{array}{c}\text { Table } 1 \\
\text { (degree) }\end{array}$} \\
\cline { 2 - 5 } & Warp & Weft & Warp & Weft \\
\hline 1 & 62 & 88 & 42 & 72 \\
\hline 2 & 66 & 85 & 50 & 70 \\
\hline 3 & 60 & 80 & 44 & 70 \\
\hline 4 & 58 & 84 & 40 & 66 \\
\hline 5 & 64 & 74 & 40 & 64 \\
\hline 6 & 68 & 70 & 44 & 68 \\
\hline 7 & 63 & 72 & 42 & 66 \\
\hline 8 & 60 & 76 & 40 & 60 \\
\hline 9 & 60 & 80 & 38 & 56 \\
\hline 10 & 60 & 88 & 38 & 62 \\
\hline 11 & 52 & 80 & 42 & 66 \\
\hline 12 & 55 & 80 & 44 & 64 \\
\hline 13 & 58 & 82 & 40 & 62 \\
\hline 14 & 54 & 80 & 36 & 68 \\
\hline 15 & 54 & 80 & 44 & 58 \\
\hline & & & & \\
\hline
\end{tabular}

Tear strength test results applied to antibacterial treated and untreated fabrics are shown in table 2. Each value in table 2 is the arithmetic mean of 5 different tear strengths. As seen in table 1, after the antibacterial finishing process, there was a decrease in the creasing strength (angle) of both warp and weft direction.

Comparing Greige fabric and antibacterial finishing fabric wrinkle testin figure 1 , it is clearly seen that antibacterial fabrics affect negatively wrinkle angle. After the antibacterial finishing process, the tear strength decreased in both warp and weft directions (table 2 and figure 2). There was an increase in abrasion resistance after antibacterial finishing (table 3).

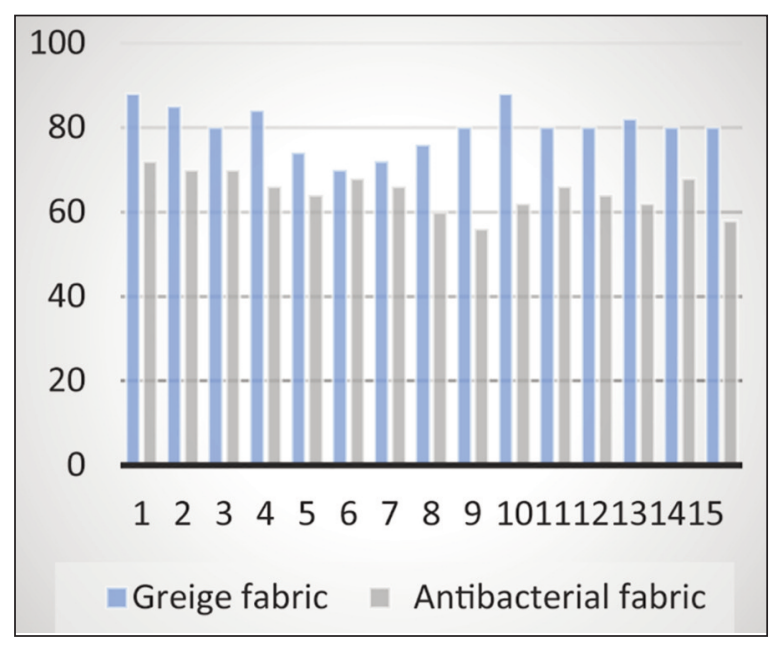

a

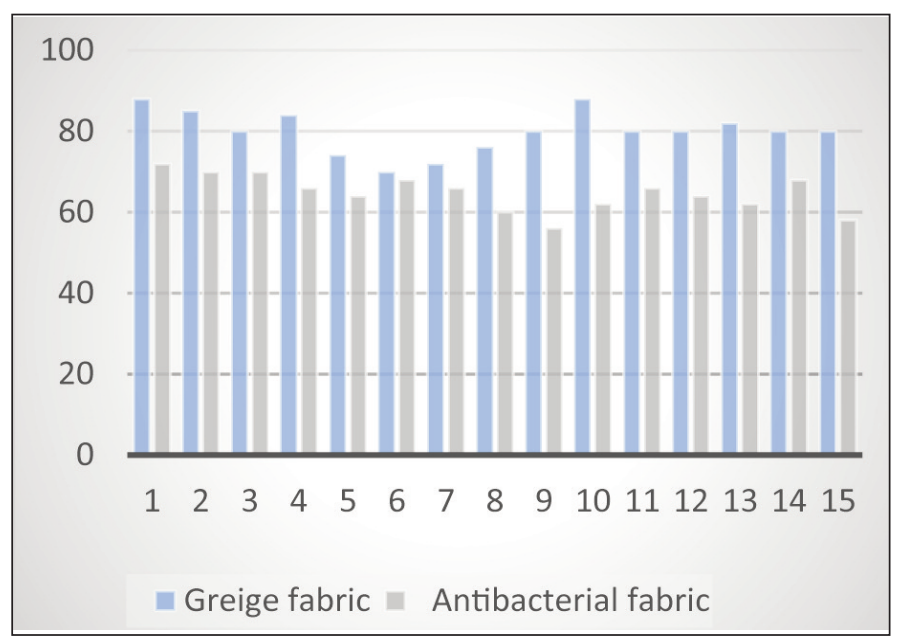

b

Fig. 1. Greige fabric and the antibacterial finishing fabric are compared with wrinkle test:

$a-$ Wrinkle test warp direction; $b$ - Wrinkle test weft direction 


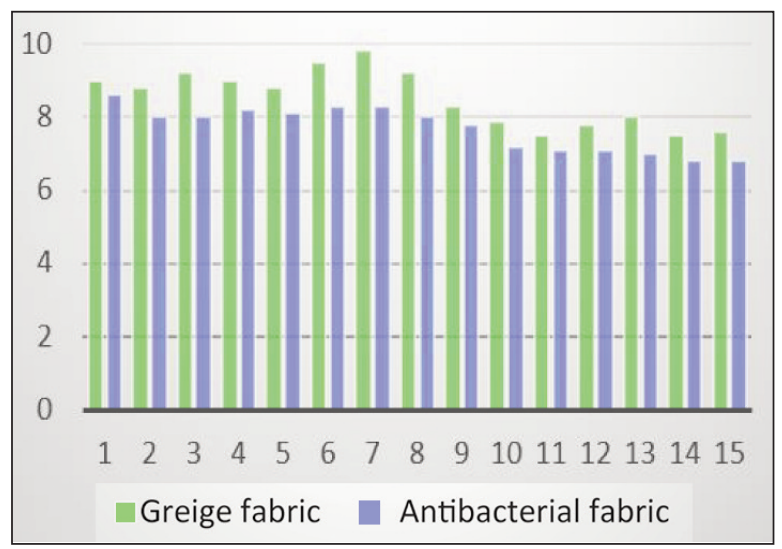

a

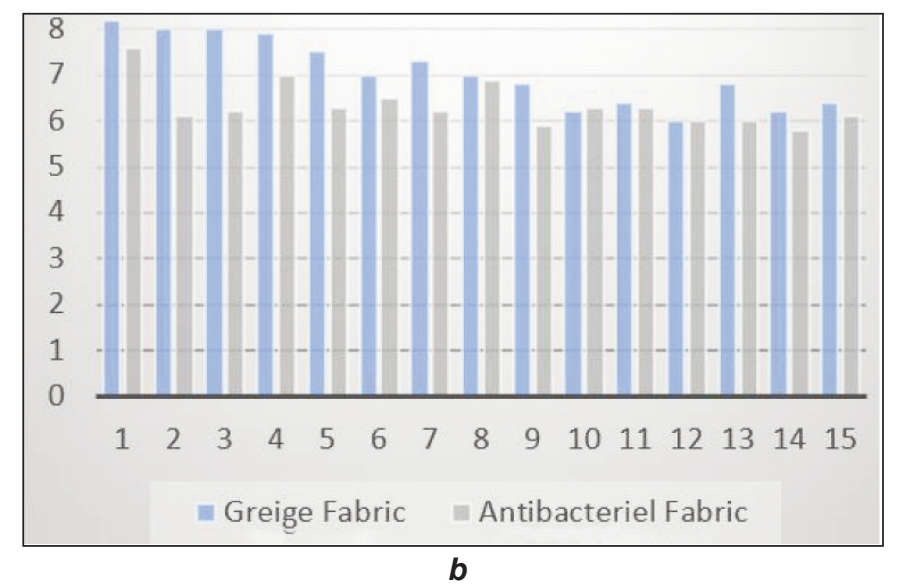

b

Fig. 2. Greige fabric and the antibacterial finishing fabric are compared with the creasing strength levels: $a$ - tear streght with warp direction; $b$ - tear streght with weft direction

Table 2

TEAR STRENGTH TEST RESULTS (TS EN ISO 13937-1)

\begin{tabular}{|c|c|c|c|c|}
\hline \multirow{2}{*}{ Samples } & \multicolumn{2}{|c|}{$\begin{array}{c}\text { Greige fabric } \\
\text { (N) }\end{array}$} & \multicolumn{2}{c|}{$\begin{array}{c}\text { Antibacterial fabric } \\
\text { (N) }\end{array}$} \\
\cline { 2 - 5 } & $\begin{array}{c}\text { Warp } \\
\text { direction }\end{array}$ & $\begin{array}{c}\text { Weft } \\
\text { direction }\end{array}$ & $\begin{array}{c}\text { Warp } \\
\text { direction }\end{array}$ & $\begin{array}{c}\text { Weft } \\
\text { direction }\end{array}$ \\
\hline 1 & 9.0 & 8.2 & 8.6 & 7.6 \\
\hline 2 & 8.8 & 8.0 & 8.0 & 6.1 \\
\hline 3 & 9.2 & 8.0 & 8.0 & 6.2 \\
\hline 4 & 9.0 & 7.9 & 8.2 & 7.0 \\
\hline 5 & 8.8 & 7.5 & 8.1 & 6.3 \\
\hline 6 & 9.5 & 7.0 & 8.3 & 6.5 \\
\hline 7 & 9.8 & 7.3 & 8.3 & 6.2 \\
\hline 8 & 9.2 & 7.0 & 8.0 & 6.9 \\
\hline 9 & 8.3 & 6.8 & 7.8 & 5.9 \\
\hline 10 & 7.9 & 6.2 & 7.2 & 6.3 \\
\hline 11 & 7.5 & 6.4 & 7.1 & 6.3 \\
\hline 12 & 7.8 & 6.0 & 7.1 & 6.0 \\
\hline 13 & 8.0 & 6.8 & 7.0 & 6.0 \\
\hline 14 & 7.5 & 6.2 & 6.8 & 5.8 \\
\hline 15 & 7.6 & 6.4 & 6.8 & 6.1 \\
\hline
\end{tabular}

Martindale Abrasion and Pilling gauge test on the sample fabrics was made in accordance with the TS EN ISO 12947-1 standard (table 3).

The results of greig and antibacterial fabric abrasion clearly show that the antibacterial process contributes greatly to the greig fabric in terms of abrasion in figure 3 .

In table 4 , the normality and homogeneity assumptions of the data distributions obtained from the processes applied to the greige fabric and antibacterial treated fabrics were examined. The results of Shapiro-Wilk statistic scores of both fabrics are not significant compared to $p>0.05$, it is concluded that all score distributions meet the normality assumption, that is, normal distribution. According to Levene homogeneity test results, it is concluded that test
Table 3

\begin{tabular}{|c|c|c|}
\hline \multicolumn{3}{|c|}{$\begin{array}{c}\text { MARTINDALE ABRASION RESISTANCE TEST } \\
\text { RESULTS (TS EN ISO 12947-1) }\end{array}$} \\
\hline Samples & $\begin{array}{c}\text { Greige fabric } \\
\text { (Tour) }\end{array}$ & $\begin{array}{c}\text { Antibacterial fabric } \\
\text { (Tour) }\end{array}$ \\
\hline 1 & 18150 & 19750 \\
\hline 2 & 19050 & 19650 \\
\hline 3 & 18100 & 19800 \\
\hline 4 & 18800 & 19900 \\
\hline 5 & 18250 & 19850 \\
\hline 6 & 18300 & 19350 \\
\hline 7 & 19050 & 19450 \\
\hline 8 & 19000 & 19400 \\
\hline 9 & 19100 & 19450 \\
\hline 10 & 18900 & 19400 \\
\hline 11 & 19000 & 19500 \\
\hline 12 & 18850 & 19450 \\
\hline 13 & 18850 & 19450 \\
\hline 14 & 18950 & 19750 \\
\hline 15 & 18900 & 19800 \\
\hline
\end{tabular}

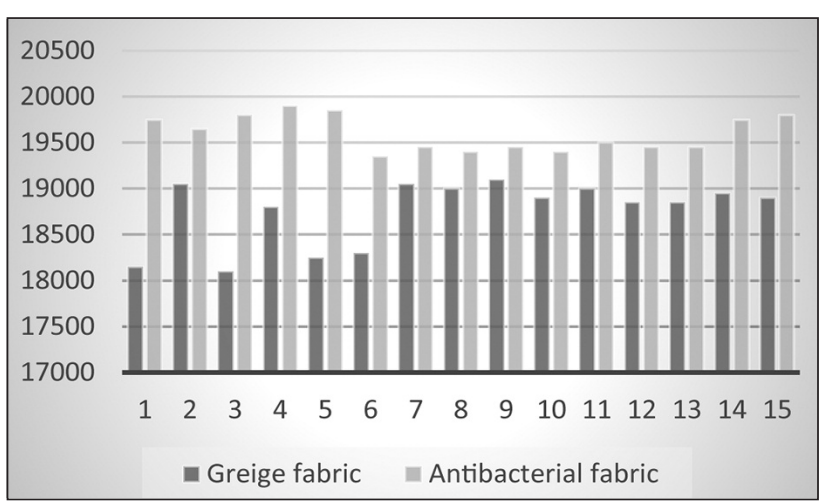

Fig. 3. Asbrasion resistance levels of the greige fabric and the antibacterial treated fabric are compared

variances according to $p>0.05$ are distributed homogeneously, that is, they meet the assumption of homogeneity. It is seen that the distribution of the 
SHAPIRO-WILK NORMALITY TEST AND LEVENE HOMOGENEITY TEST, * $p<0.05$

\begin{tabular}{|c|c|c|c|c|c|c|c|}
\hline \multirow{2}{*}{ Group } & \multirow{2}{*}{ Fabric } & \multirow{2}{*}{ Group } & \multicolumn{3}{|c|}{ Shapiro-Wilk } & \multicolumn{2}{|c|}{ Levene Homogeneity Test } \\
\hline & & & Statistic & sd & p & $F(1-28)$ & $\mathbf{p}$ \\
\hline \multirow{4}{*}{$\begin{array}{l}\text { Wrinkle strength } \\
\text { (wrinkle angle) }\end{array}$} & \multirow{2}{*}{ Greige fabric } & Warp & 0.969 & 15 & 0.838 & 10.201 & 0.282 \\
\hline & & Weft & 0.936 & 15 & 0.331 & 0.000 & 0.988 \\
\hline & \multirow{2}{*}{$\begin{array}{l}\text { Antibacterial } \\
\text { treated fabric }\end{array}$} & Warp & 0.928 & 15 & 0.254 & 1.201 & 0.282 \\
\hline & & Weft & 0.971 & 15 & 0.866 & 0.000 & 0.988 \\
\hline \multirow{4}{*}{ Tear strength $(\mathrm{N})$} & \multirow{2}{*}{ Greige fabric } & Warp & 0.923 & 15 & 0.217 & 1.615 & 0.214 \\
\hline & & Weft & 0.927 & 15 & 0.243 & 1.816 & 0.156 \\
\hline & \multirow{2}{*}{$\begin{array}{l}\text { Antibacterial } \\
\text { treated fabric }\end{array}$} & Warp & 0.888 & 15 & 0.062 & 1.615 & 0.214 \\
\hline & & Weft & 0.945 & 15 & 0.456 & 1.816 & 0.156 \\
\hline \multirow{2}{*}{$\begin{array}{l}\text { Martin deal abrasion } \\
\text { resistant test } \\
\text { (number of tours) }\end{array}$} & Greige fabric & Greige fabric & 0.917 & 15 & 0.202 & 1.865 & 0.063 \\
\hline & $\begin{array}{l}\text { Antibacterial } \\
\text { treated fabric }\end{array}$ & $\begin{array}{c}\text { Antibacterial } \\
\text { fabric }\end{array}$ & 0.896 & 15 & 0.142 & 1.865 & 0.063 \\
\hline
\end{tabular}

points obtained from the data is continuous data and at the level of equal intervals.

The sampling of these two fabrics is independent of each other, the dependent variables are measured at the range or ratio scale level, and the assumptions of normality and homogeneity meet the parametric test assumptions.

According to table 1, after the antibacterial finishing process, the shrinkage strength (angle) decreased in both warp and weft direction. According to table 2, after the antibacterial finishing process, the tear strength decreased in both warp and weft direction. According to table 3 , there was an increase in the abrasion resistance after antibacterial finishing.

In table 5, the wrinkle strength levels of greige fabric and antibacterial treated fabric are compared in terms of warp. Wrinkle strength (angle) in terms of warp of greige fabric ( $\bar{X}=59.60$ degree) and crease strength (angle) in terms of warp to antibacterial treated fabric $(\bar{X}=41.60$ degree $), t_{(14)}=14.91$, It is seen that there is a significant difference according to $p=0.000<0.05$. After the greige fabric is treated with antibacterial, it is seen that the creasing strength (angle) decreases in terms of warp, that is, the decrease of this angle is perceived as a negative result. In this respect, in order to reduce the creasing angle, the greige fabric should be treated with antibacterial in terms of warp.

Table 6 is examined, it is seen that in terms of weft, the greige fabric and the antibacterial finishing fabric are compared with the creasing strength levels. $t_{(14)}=8.9$, between the crease strength $(\bar{X}=79.93$ degre) in terms of weft of the greige fabric and the crease resistance $(\bar{X}=64.80$ degre) in terms of weft to the antibacterial treated fabric It is seen that there is a significant difference according to $p=0.000<$ 0.05 . After the greige fabric is treated with antibacterial, it is seen that the creasing strength (angle) decreases in terms of weft, that is, the reduction of this angle is perceived as a negative result. In this respect, in order to reduce the creasing angle, the greige fabric should be treated with antibacterial in terms of weft.

PAIRED-SAMPLE T-TEST RESULTS REGARDING THE DIFFERENCE BETWEEN LEVELS OF WRINKLE STRENGTH IN TERMS OF GREIGE FABRIC AND ANTIBACTERIAL TREATED FABRIC , * $p<0.05$

\begin{tabular}{|c|c|c|c|c|c|c|c|}
\hline Parameter & Warp direction & No. & Mean & S & t & sd & p \\
\hline \multirow{2}{*}{ Wrinkel strength } & Greige fabric & 15 & 59.60 & 4.60 & \multirow{2}{*}{14.91} & \multirow{2}{*}{14} & \multirow{2}{*}{$0.000^{*}$} \\
\cline { 2 - 8 } & Antibacterial treated fabric & 15 & 41.60 & 3.40 & & & \\
\hline
\end{tabular}

DIFFERENCES BETWEEN WEFT CREASING STRENGTH (ANGLE) OF GREIGE FABRIC AND ANTIBACTERIAL TREATED FABRICS

\begin{tabular}{|c|c|c|c|c|c|c|c|}
\hline Parameter & Weft direction & No. & Mean & $\mathbf{S}$ & $\mathbf{t}$ & $\mathbf{s d}$ & $\mathbf{p}$ \\
\hline \multirow{2}{*}{ Wrinkel strength } & Greige fabric & 15 & 79.93 & 5.27 & \multirow{2}{*}{8.97} & \multirow{2}{*}{14} & \multirow{2}{*}{$0.000^{*}$} \\
\cline { 2 - 8 } & Antibacterial treated fabric & 15 & 64.80 & 4.59 & & & \\
\hline
\end{tabular}


T-TEST RESULTS REGARDING THE DIFFERENCE BETWEEN TEAR STRENGTH LEVELS IN TERMS OF RAW WARP DIRECTION AND ANTIBACTERIAL TREATED FABRIC WARP, ${ }^{*} p<0.05$

\begin{tabular}{|c|c|c|c|c|c|c|c|}
\hline Parameter & Warp direction & No. & Mean & $\mathbf{S}$ & $\mathbf{t}$ & $\mathbf{s d}$ & $\mathbf{p}$ \\
\hline \multirow{2}{*}{ Tear strength } & Greige fabric & 15 & 8.53 & 0.77 & \multirow{2}{*}{10.16} & \multirow{2}{*}{14} & \multirow{2}{*}{$0.000^{*}$} \\
\cline { 2 - 9 } & Antibacterial treated fabric & 15 & 7.69 & 0.62 & & & \\
\hline
\end{tabular}

Table 8

T-TEST RESULTS REGARDING DIFFERENCE BETWEEN TEAR STRENGTH LEVELS IN TERMS OF GREIGE FABRIC AND ANTIBACTERIAL TREATED FABRIC, ${ }^{*} \mathrm{p}<0.05$

\begin{tabular}{|c|c|c|c|c|c|c|c|}
\hline Parameter & Weft direction & No. & Mean & S & t & sd & p \\
\hline \multirow{2}{*}{ Tear strength } & Greige fabric & 15 & 7.05 & 0.74 & \multirow{2}{*}{4.41} & \multirow{2}{*}{14} & \multirow{2}{*}{$0.001^{*}$} \\
\cline { 2 - 9 } & Antibacterial treated fabric & 15 & 6.35 & 0.48 & & & \\
\hline
\end{tabular}

\begin{tabular}{|c|c|c|c|c|c|c|c|}
\hline \multicolumn{8}{|c|}{$\begin{array}{l}\text { T-TEST RESULTS REGARDING THE DIFFERENCE BETWEEN THE ABRASION RESISTANCE } \\
\text { STRENGTH LEVELS OF GREIGE FABRIC AND ANTIBACTERIALLY TREATED FABRIC, * }{ }^{*}<0.05\end{array}$} \\
\hline Parameter & Fabric type & No. & Mean & $\mathbf{S}$ & $\mathbf{t}$ & sd & $\mathbf{p}$ \\
\hline \multirow{2}{*}{$\begin{array}{l}\text { Abrasion resistant } \\
\text { strength }\end{array}$} & Greige fabric & 15 & 18750.00 & 355.57 & \multirow{2}{*}{7.03} & \multirow{2}{*}{14} & \multirow{2}{*}{$0.000^{*}$} \\
\hline & Antibacterial treated fabric & 15 & 19596.67 & 193.16 & & & \\
\hline
\end{tabular}

As seen in figure 2, antibacterial treatment negatively affected the tear strength of Greige fabric and antibacterial finish fabric tear strength results.

According to table 7 , the tear strength levels of the greige fabric and the antibacterial treated fabric are compared in terms of warp. Between tear strength mean $(\bar{X}=8.53 \mathrm{~N})$ of warp in terms of warp and tear strength mean $(\bar{X}=7.69 \mathrm{~N})$ of antibacterial treated fabric in terms of warp $t_{(14)}=10.16$, It is seen that there is a significant difference according to $p=0.000$ $<0.05$. After the greige fabric is treated with antibacterials, it is seen that the tear strength (Newton) decreases in terms of warp, that is, the decrease in this weight is perceived as a negative result. It is seen that antibacterial finishing process negatively affects the weft tear strength.

In table 8, the tear strength levels of the greige fabric and the antibacterial treated fabric are compared in terms of weft. $t_{(14)}=4.41$, between the tear strength $(\bar{X}=7.05$ newton) in terms of weft of the greige fabric and the tear strength ( $\bar{X}=6.35$ newton) in the antibacterial treated fabric It is seen that there is a significant difference according to $p=0.001<0.05$. After the greige fabric is treated with antibacterials, it is seen that the tear strength (newton) decreases in terms of weft, that is, the decrease in this weight is perceived as a negative result. It is seen that the antibacterial finishing process negatively affects the warp tear strength.

According to table 9, the abrasion resistance levels of the greige fabric and the antibacterial treated fabric are compared. Abrasion resistance strength (number of tours) of greige fabric $(\bar{X}=18750.00)$ and abrasion resistance (number of tours) of fabric treated with antibacterials $(\bar{X}=19596.67) t_{(14)}=7.03, p=0.000<$ 0.05 It is seen that there is a significant difference. It is seen that the abrasion resistance (number of turns) increases after the greige fabric is treated with antibacterial. In this respect, it is seen that the antibacterial process has a positive effect on fabric abrasion resistance.

After antibacterial finishing, there was a decrease in the creasing strength (angle) of both warp and weft direction. In other words, sheets with antibacterial finishing are wrinkled more. Wrinkle angle of flexible fabrics is higher. Since the antibacterial finishing process reduces fabric flexibility, it negatively affected the creasing angle of the treated fabric. In addition, the antibacterial finishing process creates extra weight on the fabric, and the wrinkle angle may be adversely affected after the applied force. As a result of Sema Palamutcu et al. 2008 project, it was observed that the fabric tear strength decreased after antibacterial treatment [14]. These results support the results of our thesis. There was an increase in abrasion resistance after antibacterial finishing. In other words, sheets with antibacterial finishing are less and hard to wear. We can say that there is an increase in the abrasion resistance since the chemical surface is coated with an antibacterial finishing process.

\section{CONCLUSIONS}

A good antibacterial activity was observed against the MRSA isolate in the fabric, and it was observed 
that the fabric showed a weak antibacterial activity against the $E$. coli isolate. The effectiveness of the antibacterial activity will decrease, depending on the type of chemical substance that shows antibacterial effect, the duration of its activity on the fabric, the physical factors such as washing and tearing.

After the antibacterial finishing process, the wrinkle strength (angle) of warp and weft direction decreases, so these sheets become more wrinkled. Wrinkle angle of flexible fabrics is higher. Since the antibacterial finishing process reduces fabric flexibility, it negatively affected the creasing angle of the treated fabric. In addition, the antibacterial finishing process creates extra weight on the fabric and the wrinkle angle may be adversely affected after the applied force.

After the antibacterial finishing process, the tear strength decreased in both warp and weft directions. In other words, sheets with antibacterial finishing treatment can be torn more easily. The tear strength of flexible fabrics is higher as the yarns can slip more easily over each other. Since the antibacterial finishing process reduces fabric flexibility, a reduction in tear strength occurred.

In the conclusion of Huriser Balcı's thesis study in 2006, the characteristics that antibacterial process parameters negatively affect cotton fabric; tensile tensile, tear strength, creasing properties, water and sweat fastness [15]. As a result of Sema Palamutçu et al. 2008 project, the decrease in fabric tear strength after antibacterial treatment supports the study [14]. There was an increase in abrasion resistance after antibacterial finishing. An improvement has been observed in this regard. It can be said that there is an increase in the abrasion resistance since the chemical surface is coated with antibacterial finishing process. Wrinkle strength, tear strength; the positive effect was the abrasion resistance. Along with the antibacterial process applied in the studies to be carried out, it should definitely be evaluated in decreases in the mechanical properties besides the feature to be gained to the fabric.

The studies that can be done in the next periods are mentioned respectively. Comparison can be made with different chemical structured antibacterial finishing agents by applying finishing to fabrics of different weaving types. Relationships between different mechanical properties such as tensile strength, seam strength, bursting strength can be examined by antibacterial finishing.

Antibacterial finishing process; chemical properties such as fastness and sensory properties such as attitude and touch can be examined.

\section{REFERENCES}

[1] Akaydin, M., Kalkanci, M., Hastane Giysisi Olarak Kullanılan Kumaşların Antibakteriyel Özellikleri Üzerine Bir Araştırma, In: SDU J. Sci., 2014, 9, 1, 20-34

[2] Ünal, H., Development Of Disposable Hydrophilic And Antibacterial Polypropylene Nonwoven Sheet, Yüksek Lisans Tezi, İstanbul Teknik Üniversitesi Fen Bilimleri Enstitüsü, Tekstil Mühendisliği Anabilim Dalı, 2009

[3] Tomasino, C., Chemistry \& Technology of Fabric Preperation \& Finisihin, North Carolina State University Publication, Raleigh, 1992

[4] Perelshtein, L., Applerot, G., Perkas, N., Guibert, G., Mikhailov, S., Gedanken, A., Sonochemical coating of silver nanoparticles on textile fabrics (nylon, polyester and cotton) and their antibacterial activity, In: Nanotechnology, 2008, 19, 24

[5] Balakumarana, M.D., Ramachandrana, R., Jagadeeswarib, S., Kalaichelvana, P.T., In vitro biological properties and characterization of nanosilver coated cotton fabrics - An application for antimicrobial textile finishing, In: International Biodeterioration \& Biodegradation, 2016, 107, 48-55

[6] Haytham, M.M., Mahmoud, I., Hassanb, S., Characterization and antimicrobial properties of cotton fabric loaded with green synthesized silver nanoparticles, In: Carbohydrate Polymers, 2016, 151, 841-850

[7] Thanh, N.V.K., Phong, N.T.P., Investigation of antibacterial activity of cotton fabric incorporating nano silver colloid, In: APCTP - Asean Workshop on Advanced Materials Science and Nanotechnology (AMSN08), 15-21 September 2008

[8] Mohammadi, M.R., Production of cotton fabrics with durable antibacterial property by using gum tragacanth and silver, In: International Journal of Biological Macromolecules, 2018, 109, 476-482

[9] Kittinaovarat, S., Kantuptim, P., Singhaboonponp, T., Wrinkle resistant properties and antibacterial efficacy of cotton fabrics treated with glyoxal system and with combination of glyoxal and chitosan system, In: Journal of Applied Polymer Science, 2006, 100, 2, 1372-1377

[10] Xu, Q.B., Xie, L.J., Diao, H., Li, F., Zhang, Y.Y., Fu, F.Y., Liu, X.D., Antibacterial cotton fabric with enhanced durability prepared using silver nanoparticles and carboxymethyl chitosan, In: Carbohydrate Polymers, 2017, 177, 187-193

[11] Xu, Q., Gu, J., Zhao, Y., Ke, X.T., Liu, X.D., Antibacterial cotton fabric with enhanced durability prepared using L-cysteine and silver nanoparticles, In: Fibers and Polymers, 2017, 18, 2204-2211

[12] Ramachandran, T., Rajendrakumar, K., Rajendran, R., Antimicrobial Textiles an Overview, IE (I) Journal TX, 2004,84 
[13] Özdil, N., Kumaşlarda Fiziksel Kalite Kontrol Yöntemleri, In: Tekstil ve Konfeksiyon Araştırma - Uygulama Merkezi Yayini, 2016, 167

[14] Palamutcu, S., Şengül, M., Devrent, N., Keskin, R., Tekstil Ürünlerinde Antimikrobiyal Etkinlik Belirleme Testleri, VII. Ulusal Ölçübilim Kongresi, 30 Ekim -1Kasım, 2008

[15] Balci, H., Akıllı (Fonksiyonel) Tekstiller, Seçilmiş Kumaşlarda Antibakteriyel Apre Ve Performans Özellikleri, Yüksek Lisans Tezi, Çukurova Üniversitesi Fen Bilimleri Enstitüsü, Tekstil Müh. Anabilim Dali, 2006

\section{Authors: \\ AKPINAR ELIF SULTAN ${ }^{1}$, KAPLAN VOLKAN² ${ }^{2}$ CAN YAHYA ${ }^{3}$}

${ }^{1}$ Giresun University Textile Technology Department Associate's Degree Şebinkarahisar Teknik Bilimler Meslek Yüksekokulu - Tekstil Teknolojisi, Giresun, Turkey email: elif.sultan.akpinar@giresun.edu.tr

2Pamukkale University Textile Engineering Department, Kinikli Campus, 20020, Denizli, Turkey

${ }^{3}$ Pamukkale University Textile Engineering Department Associate's Degree PAU Teknik Bilimler MYO,

Camlik, 20020, Denizli, Turkey

email: ycan@pau.edu.tr

\section{Corresponding author:}

KAPLAN VOLKAN

e-mail: volkank@pau.edu.tr 